\title{
GLANZMANN'S THROMBASTHENIA AS A CAUSE FOR SECONDARY POSTPARTUM HAEMORRHAGE
}

\author{
Deepa Kalaㅁ, Bindu K. S², Jayanth Chilkund ${ }^{3}$
}

${ }_{1}^{1}$ Professor, Department of Obstetrics \& Gynaecology, Terna Medical College and Consultant in OBGY at Terna Sahyadri Speciality Hospital and Research Centre, Navi Mumbai.

${ }^{2}$ Consultant, Department of Obstetrics \& Gynaecology, Terna Sahyadri Speciality Hospital and Research Centre, Navi Mumbai and Fortis Hospital, Vashi, Navi Mumbai.

${ }_{3}^{3}$ Medical Officer, Gynaecologist at Pt. MMM Shatabdi Hospital, Govandi, Mumbai.

\section{ABSTRACT}

\section{BACKGROUND}

Glanzmann's thrombasthenia is an inherited haemorrhagic disorder associated with high risk for mother and foetus due to intraand postpartum haemorrhage. Platelet counts, platelet morphology, prothrombin and activated thromboplastin times are all within normal ranges in patients with Glanzmann's thrombasthenia and diagnosis is only by platelet aggregation studies which may not be easily available. Knowledge and suspicion on history of some bleeding disorder helps to diagnose and prepare early.

\section{KEYWORDS}

Glanzmann's Thrombasthenia, Secondary Postpartum Haemorrhage.

HOW TO CITE THIS ARTICLE: Kala D, Bindu KS, Chilkund J. Glanzmann's thrombasthenia as a cause for secondary postpartum haemorrhage. J. Evolution Med. Dent. Sci. 2016;5(28):1468-1469, DOI: 10.14260/jemds/2016/345

\section{INTRODUCTION}

Glanzmann's thrombasthenia is an inherited haemorrhagic disorder characterized by a severe reduction in or absence of platelet aggregation in response to multiple physiologic agonists due to qualitative or quantitative abnormalities of platelet glycoprotein IIb-IIIa. The disorder usually manifests as severe mucocutaneous bleeding in childhood, menstrual patterns in pubertal-adolescent years, rarely life-threatening. Hence, it is important to be aware of the entity and complete the haematological studies. Pregnancy and delivery are rare in Glanzmann's thrombasthenia patients and are associated with high risk for mother and foetus due to intra- and postpartum haemorrhage.

\section{CASE REPORT}

A 30-year-old P1L1 presented three months post-delivery, which was by caesarean section [LSCS] with secondary PostPartum Haemorrhage [PPH]. Patient had followed up two weeks post LSCS for similar complaint, but bleeding had stopped with antifibrinolytics and tab methergine.

Patient had history of bleeding from injection site after second dose of Tetanus Toxoid injection at twenty eight weeks of pregnancy and was referred to haematologist for the same.

All routine haematological investigations were within normal limits. Patient was advised platelet aggregation studies, which was not done. She had emergency LSCS at 39 weeks with blood and FFP kept ready. Fortunately, there was no complication of haemorrhage during LSCS and in the immediate postoperative period. Sutures were removed on day seven and patient was healthy. Patient was admitted now

\footnotetext{
Financial or Other, Competing Interest: None.

Submission 17-02-2016, Peer Review 12-03-2016,

Acceptance 19-03-2016, Published 07-04-2016.

Corresponding Author:

Dr. Deepa Kala,

C 94, Block No. 33, Kendriya Vihar CHS,

Sector 38, Nerul (West),

Navi Mumbai-400706,

Maharashtra, India.

E-mail: dkala24@yahoo.com

DOI: $10.14260 /$ jemds $/ 2016 / 345$
}

in Intensive Care Unit [ICU] for increased per vaginal bleeding, haemoglobin of $8 \mathrm{gm}$ percent.

Uterus was well retracted and no signs of trauma were present. She was treated with packed cells transfusion for build-up of haemoglobin and started on misoprost, antifibrinolytics and methergine tablets. Bleeding continued to recur, so oral progesterone was also started. Still on the third day the bleeding was not completely stopped and hence Foley's catheter was inserted in the uterus for uterine tamponade. Haematological reference was sought in view of her incomplete antenatal workup and history of menorrhagia, increased bleeding during dental extraction and increased bleeding from cuts and wounds got on probing.

The plan was uterine angiography or recombinant factor 7 transfusion after complete haematological workup. Investigation revealed patient had Glanzmann's thrombasthenia. Patient was then treated as per haematologist's advice with single donor platelet transfusion, injection ferric carboxymaltose. Foley's catheter was removed after the platelet transfusion. Platelet transfusion was repeated after one week and then patient was finally discharged with advice for followup.

\section{DISCUSSION}

Glanzmann's thrombasthenia is a rare disorder, but can lead to life-threatening haemorrhage in pregnancy and puerperium and also for the newborn.(1,2) Platelet counts, platelet morphology, prothrombin and activated thromboplastin times are all within normal ranges in patients with Glanzmann's thrombasthenia and diagnosis is only by platelet aggregation studies.

All these studies may not be easily available everywhere. The treatment of acute haemorrhage mainly with platelet transfusions also leads to a high cost. Knowledge and suspicion on history of some bleeding disorder helps to diagnose and prepare early.

Pregnancy in women with Glanzmann's thrombasthenia requires multidisciplinary management, preferably at a tertiary care centre. The need for prevention and aggressive treatment of PPH and minimization of foetal bleeding risk in pregnancies, complicated by alloimmunization should be 
recognised while planning for the delivery of these women.(2) rFVIIa is effective for severe bleeding in Glanzmann thrombasthenia patients, especially in those with antiplatelet antibodies and/or platelet transfusion refractoriness. (1)

When patient is not responding to platelet transfusions other causes of secondary PPH must also be ruled out simultaneously.

\section{REFERENCES}

1. Uchikova E, Pechlivanov B, Parahuleva N, et al. Glanzmann thrombasthenia and pregnancy-report of a case and literature review. Akush Ginekol (Sofiia) 2014;53(5):4951.

2. Siddiq S, Clark A, Mumford A. A systematic review of the management and outcomes of pregnancy in glanzmann thrombasthenia. Haemophilia 2011;17(5):858-69. 